Originalni naučni rad

271.22(497.11)(436+439)

doi:10.5937/zrpfns53-19345

Marko D. Tomić, Ph.D. Student

University of Belgrade

Faculty of Law Belgrade

tomicmarko@hotmail.com

\title{
THE VIEW ON THE LEGAL POSITION OF THE SERBIAN ORTHODOX CHURCH IN BOSNIA AND HERZEGOVINA UNDER THE RULE OF THE AUSTRO-HUNGARIAN EMPIRE*
}

\begin{abstract}
Certain aspects of the initial phase of the process of incorporation of the Serbian metropolitanates in Bosnia and Herzegovina into the state-legal system of Austria-Hungary from the church-law, i.e., canonical aspect, are the subject of this paper. The legal status of the Serbian metropolitanates in BH during the time period following the Congress of Berlin was being settled between Vienna and Constantinople. The final outcome of the negotiations between the Patriarchate of Constantinople and the Viennese Court was the Convention from the year of 1880 on temporary solution to the relations between the Serbian Orthodox metropolitanates in $\mathrm{BH}$ and the Patriarchate of Constantinople. The main part of the paper is about the analysis of the Convention provisions concerning the selection and dismissal of a higher hierarchy from the church-law aspect. Then, on the basis of the concrete examples from the Church life, an estimation of these events from the perspective of the Canon law is given.
\end{abstract}

Keywords: Serbian Orthodox Church in Bosnia and Herzegovina, Austria-Hungary, the Patriarchate of Constantinople, hierarchy, church (canonic) law.

\section{INITIAL REMARKS}

Historic events in Bosnia and Herzegovina from the Congress of Berlin until the outbreak of the WWI were an introduction into the final settlement of the issue pertaining to the further presence of the Ottoman Empire in the areas populated by the Serbian people. It was obvious that the period of Ottoman domination had come to its end, and now the Austro-Hungarian monarchy was the 
one tending to take over the role of the leading power in the Balkans. Events taking place in Bosnia and Herzegovina during these 30 or so years have been written about not just from the historical, but from the cultural, political, and legal aspect as well. ${ }^{1}$

Church historians analyse this period, mainly, as a part of their comprehensive studies $^{2}$ and examine a very complex position of the Serbian Orthodox metropolitanates in $\mathrm{BH}$ from this period with no detailed approach.

Explorers (V. Skarić, O. Nuri-Hadžić, N. Stojanović, V. Bogićević, R. Grđić, S. Stanojević, T. Kraljačić, V. Ćorović, and others) treating the issue of BH history during the cited period, have provided general information and mainly deal with the topic of the struggle of the Serbs, Croats, and Muslims for a religious and educational autonomy. ${ }^{3}$ Some historians have addressed the issue of the Serb national movement in $\mathrm{BH}$ coming into being and expanding, as well as its fight for religious and educational autonomy. The fight had several phases and forms, and the Serbian Orthodox metropolitanates played a crucial role in its final outcome.

${ }^{1}$ For the sake of clarity, it is to be mentioned that the Serbian Orthodox Church in BH, during the Austro-Hungarian period, did not bear the name from the title here officially. However, since it is an expression widely used in the local historiography, it has therefore been given in the title itself. The official name was the Serbian Orthodox Metropolitanates in BH (under the jurisdiction of the Patriarchate of Constantinople). The two terms are alternatively used in this paper.

For more detailed information on the cultural, political, economic, and legal aspects of the historic events from this period see the works of Milorad Ekmečić - „Društvo, privreda i socijalni nemiri u BiH", and "Nacionalni pokret u BiH" Istorija srpskog naroda VI-1, Belgrade, 555-648, 1994.

${ }^{2}$ The most significant studies of church historians are: Djoko Slijepčević, Istorija Srpske pravoslavne crkve, Book II, Od početka XIX vijeka do kraja Drugog svjetskog rata, Zemun 2002; Nićifor Dučić, Istorija Srpske pravoslavne crkve (since the first decades of 7th century till nowadays), Gacko 2002; Svetislav Davidović,Srpska pravoslavna crkva u BiH (960-1930), Novi Sad 2002; Radoslav Grujić, Srpska pravoslavna crkva, Beograd- Kragujevac 1995; Sava Vuković, Srpski jerarsi od XIX do XX veka, Novi Sad 2012; Predrag Puzović, „Srpska crkva u Bosni i Hercegovini“, Srpska pravoslavna crkva - prilozi za istoriju 2, Belgrade 2000, 23-29; Sarajevska bogoslovija 1882-2002, Srbinje 2003; Srpska pravoslavna eparhija Dabro-Bosanska (šematizam), Srbinje 2004; ,Srpska pravoslavna crkva u Bosni i Hercegovini od Berlinskog kongresa do aneksije $\mathrm{BiH} 1908$ “, Collection of papers from the professional meeting „Centenary of the BH annexation“, Academy of Sciences and Arts of the Republic of Srpska, Banjaluka 2009, 65-87; Rajko Veselinović „Srpska pravoslavna crkva u Bosni i Hercegovini“, „Srpska pravoslavna crkva 1219-1969“. Spomenica o 750-godišnjici autokefalnosti, Belgrade 1969, 319-329; Jovan Dajković, „Ostavka mitropolita hadži Save Kosanovića“, SOC Gazette 40, Belgrade 1959, 112-118; Nikodim Milaš, K pitanju o jerarhičkom položaju sarajevske mitropolije, Novi Sad 1886; Dimitrije Ruvarac, Ustav crkvene i školske samouprave srpsko-pravoslavnog naroda u BiH sastavljen Dr Emilom Gavrilom, prikazan protojerejem Dimitrijem Ruvarcem, Zemun 1899.

${ }^{3}$ Tomislav Kraljajić, Kalajev režim u Bosni i Hercegovini (1882-1903), Sarajevo 1987; Vladislav Skarić, Osman Nuri-Hadžić, Nikola Stojanović,"Versko-prosvetna borba pravoslavnih Srba“, Bosna i Hercegovina pod austrougarskom upravom, Belgrade 1938, 33-55, http://www.uzzpro.gov.rs, December, $3^{\text {rd }}$ 2018; Vladimir Ćorović, Političke prilike u Bosni i Hercegovini, http://www.rastko.rs, December, $3^{\text {rd }}$ 2018; Stanoje Stanojević, Istorija Bosne i Hercegovine, http://www.rastko.rs, December, 3rd 2018. 
In his archive-based study ${ }^{4}, \mathrm{~B}$. Madžar (1982) describes the condition of the Serbian Orthodox metropolitanates in BH during this period in details, and their role in the movement for religious and educational autonomy.

Having considered the works of the mentioned authors, it is noticeable that this topic has been analysed and dealt with, but the church-law, i.e., canonic aspect of the problem in general has been put aside. On the basis of this fact, the primary aim of this paper can be set: to try to give a church-law view of the problems the Serbian Orthodox metropolitanates in $\mathrm{BH}$ were facing with following the occupation, i.e., at the very start of the incorporation process into the state-legal system of Austria-Hungary. Also, the mentioned process, long-lasting and difficult, was not finally over until 1905 when the Statute on the church and educational administration of the Serbian Orthodox eparchies in Bosnia and Herzegovina was adopted. ${ }^{5}$

\section{TRANSITIONAL PERIOD}

In order to get a general insight into the conditions in the Serbian metropolitanates, just before the Austro-Hungarian occupational troops entered $\mathrm{BH}$, some illustrative data will be given.

M. Ekmečić gives the basic data on the population in BH saying that ,the first valid census of the population in Bosnia and Herzegovina was completed in 1879 showing the total number of 1,158,164 inhabitants living in the provinces out of which 496,485 (42.88\%) were Serbs at that time." As for the class composition of the Serbian population, according to Ekmečić, it was predominantly of a rural descent and rank (87.92\%), and actually in the position of serfdom dependency on landowners, and ,the overall position and state of the Serbian people were miserable...progress of the population was threatened by the social ranking and bad habits (high rate of alcohol addicts and sick people).“6

When it comes to the school system and education, the situation was as follows: after the occupation in 1878 there were 56 Serbian primary schools in BH (with 75 teachers and 3,523 students). Government-run schools were opened as well but the law on compulsory education was not in force until $1912 .{ }^{7}$

\footnotetext{
${ }^{4}$ Božo Madžar, Pokret Srba Bosne i Hercegovine za vjersko-prosvjetnu samoupravu, Sarajevo 1982.

${ }^{5}$ In recent time, the analysis of this Statute (Ordinance), which definitely regulated the issue of church and education autonomy of Serbs in $\mathrm{BH}$, has been made by Milošević, Borivoje in the article titled as „Uredba crkveno-prosvjetne uprave srpskih pravoslavnih eparhija (mitropolija) u Bosni i Hercegovini”, Collection of papers „Stotinu dvadeset godina od početka borbe srpskog naroda u Bosni i Hercgovini za crkveno-školsku samoupravu (1869-2016)“ Banja Luka 2016, 72-88, http://www.srbiubih.com, December 2nd 2018.

${ }^{6}$ Ekmečić, M. 1994a.

${ }^{7}$ Ibid. 569-573
} 
As for the religious and spiritual issues in Serbian people during this period, according to B. Madžar, ,the level of education in clergy was very low due to backwardness in terms of general culture but also because of the system of simony, i.e., selling the priest titles. There were 374 filled parishes in Bosnia and Herzegovina (1882) with a priest working in each of them. Also, there were other 45 priests assigned to other duties." 8

As for the church-school municipalities, which were the only autonomous institutions consisted only of Serbs during the Ottoman period, and after the occupation, according to Ekmečić there were 351 such municipalities in $\mathrm{BH}$ at the end of $19^{\text {th }}$ century, but ,there were only 42 organized ones at the head of which were laymen, whereas local priests, who were mainly dealing with church issues, were at the head of 309 schools." $" 9$

These data show that the intensity of church life was reduced to a minimum, and that the people were more superstitious than devout. The Church itself was deeply divided into the Phanariot bishops who, apart from other canonic breaches, were selling priest titles mainly to individuals of questionable morality, and a lower, nearly illiterate clergy prone to malpractices that had the same faith as the poor and culturally underdeveloped people.

This means that in the institutional, cultural, and moral terms, the situation was extremely bad. The only institution that was consisted of Serbs only and was gathering relatively educated people was the church-school municipality that would later on become the pillar for the Serbs in Bosnia and Herzegovina struggling for their church and educational autonomy.

\section{THE ISSUE OF THE CANONIC STATUS OF THE SERBIAN ORTHODOX METROPOLITANATES IN BOSNIA AND HERZEGOVINA}

Since the abolition of autocephality of the Patriarchate of Peć in 1766, the Serbian Church in BH was under the canonic jurisdiction of the Patriarchate of Constantinople. Just after the proclamation of the Austro-Hungarian occupation of $\mathrm{BH}$, the new authorities immediately began redefining the relations between the Serbian Orthodox metropolitanates in BH and the Patriarchate of Constantinople. Here it is necessary to emphasize that there were several plans for the future canonic constitution of the Serbian Orthodox metropolitanates: „one of the ideas was the founding of an independent Serbian Orthodox Church in Bosnia and Herzegovina, which was an intention and the final aim of Austria-Hungary,

\footnotetext{
${ }^{8}$ Madžar, B. (1982), 68.

${ }^{9}$ Ekmečić, M. (1994a), 571.
} 
the second one was to adjoin it to the Serbian Church in Serbia, and the third one was to place it under the jurisdiction of the Patriarchate of Karlovac." 10

It was not in the interest of the new authorities to have the Serbian Orthodox metropolitanates tightly connected to Constantinople, and then via Constantinople to the Sultan because in such case they would not have a direct control over the metropolitanates. On the other hand, Vienna wanted to keep the Patriarch of Constantinople for their ally because of his church powers in the areas where the Austria-Hungary had planned the routes of its occupation policy. ${ }^{11}$

The Metropolitanate of Karlovac strongly agitated for putting the Serbian Orthodox metropolitanates under its jurisdiction. The main reasoning was that the Metropolitanate of Karlovac was a successor to the Patriarchate of Peć, and therefore having the jurisdiction rights over all the eparchies belonging to the throne of Peć until the year of 1766. Since the Serbian Church metropolitanates in $\mathrm{BH}$ now came under the power of the Austro-Hungarian Empire, it was therefore natural, in a canonical sense, to place them under the jurisdiction of the Serbian Metropolitanate of Karlovac.

Archimandrite Nikodim Milaš, the leading expert in the canonic law at the time, also proclaimed this idea referring to the canonic tradition of the Orthodox Church. ${ }^{12}$ Regardless of all of these arguments and the initial support from the Austro-Hungarian government, this idea quickly lost all of its supporters and was desisted from.

Since the Serbian Orthodox Church in Serbia regained its autocephaly in 1879, efforts were made in Belgrade to join the Serbian Orthodox metropolitanates in $\mathrm{BH}$ to the Serbian Church in Serbia. Obstruction of this unification was one of the common interests of Vienna and the Patriarchate of Constantinople.

Representatives of the Austro-Hungarian authority were referring to the two international legal acts (Article 25 from the 1878 Treaty of Berlin and the Article 2 from the 1879 April Convention, between Austria-Hungary and Turkey) while preparing for the negotiations with Constantinople. On the basis of the first act, the Austro-Hungarian representatives claimed their country's right to sovereign control over Bosnia and Herzegovina. On the basis of the second one, which was about the rights to religious freedom, they concluded that the Sultan no longer had any rights to issue beraths during the metropolitan appointment procedure in $\mathrm{BH} .{ }^{13}$ The Patriarch of Constantinople agreed to postpone the appointment of the new

\footnotetext{
${ }^{10}$ Predrag Puzović, ,Srpska pravoslavna crkva u Bosni i Hercegovini od Berlinskog kongresa do anekcije 1908. godine”, Collection of papers from the professional meeting „Stogodišnjica aneksije BiH", Banjaluka 2009, 67.

${ }^{11}$ Ibid.

${ }_{12}$ Nikodim Milaš, K pitanju o jerarhičkom položaju sarajevske mitropolije, Novi Sad 1886, 34-38.

${ }^{13}$ Madžar, B. (1982), 27.
} 
metropolitan in Sarajevo (Metropolitan Anthim had already asked for his retirement) until signing a convention with Vienna. Vienna probably obtained this delay by means of money. ${ }^{14}$

That is how the Viennese Court settled the grounds for the negotiations with the Patriarchate of Constantinople. Therefore, it was expected that the Austro-Hungarian representatives would use all legal and illegal means in order to reach the goals set. However, in doing so, they would act with an outmost precaution and attention, referring to the canonic law of the Orthodox Church when needed and breaching it when not.

After several months of negotiations, pressures and blackmails, the Patriarchate of Constantinople and Austria-Hungary signed the Convention on a temporary solution to the relations of the Serbian Orthodox metropolitanates in $\mathrm{BH}$ with the Patriarchate of Constantinople in May, 28 ${ }^{\text {th }} 1880$. At the end, the initial proposition of Vienna was adopted with minor changes made to it. The most disputable was the second item pertaining to the appointment of metropolitans. Until that time, metropolitans had been selected by the Council of Constantinople Patriarchate, and the sultan later on only formally verified it by his berath. Such circumstances were not favourable to the new authorities in BH because, in such case, the Serbian metropolitanates would be completely independent from them, and it was well known that Vienna had considered these institutions in particular as the strongest Serbian factor, the one that could jeopardize the interests of Austria-Hungary. For this reason, the Serbian Church was to be put under control.

In order to accomplish these ideas, the Austro-Hungarian representatives engaged a whole set of experts in the field of canonic law, who proved the rightfulness of the Austro-Hungarian propositions to the Patriarchate of Constantinople. Therefore, everything was done systematically and thoroughly leaving nothing to chance.

For this reason, the attempts will be made hereafter to establish the true canonic validity of the given decisions that ultimately became official provisions of the Convention between Vienna and the Patriarchate of Constantinople. It is important to mention that the Statute (Ordinance) from the year of 1905, on the basis of which the status issues of the Serbian Orthodox community in BH were finally regulated, confirmed that the 1880 Convention was to remain in power.

\section{SELECTION AND DISMISSAL OF METROPOLITANS}

While describing the „tactical outsmarting” of the Austro-Hungarian canon law experts in proving the canonic validity of the Austro-Hungarian proposals to the Patriarchate of Constantinople, B. Madžar has recorded that the „counter-proposals

${ }^{14}$ Ibid. 29. 
of the Council (of the Patriarchate of Constantinople to the suggested instruction form Vienna) caused turbulent debates in Vienna, while having the best church law experts involved." 15

The final result concerning the procedure for the selection and dismissal of metropolitans was summarized into the two following instructions offered by Vienna:

1. current metropolitans in Bosnia and Herzegovina were to stay in their positions, and changes would be possible only with a prior assent from the Patriarchate of Constantinople.

2. metropolitan vacancy, if any, would be filled only by appointments made by the Austrian Emperor. ${ }^{16}$

On the basis of these two items, it is clearly visible that the procedure for selecting and dismissing metropolitans was under a full control of the secular ruler, who was also of a Catholic denomination. The role of the Council and patriarch was reduced to a formality since the patriarch was only to confirm the emperor's choice and perform chirotony (ordination) of the new metropolitan.

This type of selection and appointment of Orthodox Church bishops represents a brutal breach of the canonic principle established a long ago. Actually, the $3^{\text {rd }}$ canon of the $7^{\text {th }}$ Ecumenical Council (held in Nicaea, in 787) precisely defines the role of authorities in the episcopal selection procedure. „Every selection of a bishop or a presbyter or a deacon coming from a potentate is to be invalid, according to the Canon that reads: Any of bishops reaching for secular powers in order to acquire a priest rank is to be removed and excommunicated, and all those in contact with him, because a bishop is to be chosen among other bishops, as instructed by our Holly Fathers in Nicaea." ${ }^{\text {"17 }}$

On the basis of this canon ${ }^{18}$ that refers to the older ones from the $4^{\text {th }}$ century, the Church attitude in terms of authority engagement in the episcopal selection is quite clear. It is important to mention here that, as early as the mid- $4^{\text {th }}$ century,

${ }^{15}$ Madžar, B. (1982), 32.

${ }^{16}$ Ibid. 30.

${ }^{17}$ Svešteni kanoni crkve, prvod sa grčkog i slovenskog Episkopa Atanasija umirovljenog Hercegovačkog (SKC) Belgrade 2005, 207-208.

${ }^{18}$ Bishop Athanasius, explaining this canon, says that it is noticeable that ,the canon is comprised of 30th Apostolic and 4th canon of Nicaea. It was necessary to repeat the two canons because at the time of Iconoclasm secular authorities were very much involved in the appointment of bishops, selecting those subservient to the heresy and politics of the Tsar, and persecuted the immune Orthodox bishops. Zonara also says that, unfortunately, that was ,,an old evil!” Rightfully, Valsamon notices that ,it is not the potentates choosing, i.e., voting for respective bishops but it is done under their pressure by some bishops because of a failure to assemble regular district Councils, which are authorized for this issue." According to Justinian's Novel 123.1 (from the year of 546, which is a part of the Syntagma in 50 titles): ,the clergy and the city leaders get together, and, after taking the unbiasedness oath, choose 3 candidates, out of which the Metropolitan and the Council get to choose one ,. SKC (2005), 208. 
theoretical concepts about the relations between the state and the Church proclaiming a clear distinction between the two had started to appear. ${ }^{19}$

This situation, which is the subject of the research, and the problems the Church was facing with at that time were not something previously unseen in its history. As far back as $8^{\text {th }}$ century, at the time of iconoclastic crises (and not only then), there had been similar problems because of the emperors' impositions of individuals eligible to them for bishops on the Church for the sake of achieving political and other interests.

Still, the historical context that is the matter of interest for this paper was different from the historical context of the mentioned example because, in this case, the ruler imposing the pressure on the episcopal selection procedure was of a different Christian denomination, but still directly imposing his solutions by avoiding and breaking all canonic rules. The above-mentioned example from the $8^{\text {th }}$ century is not about a ruler forcibly appointing bishops but rather something else.

According to N. Milaš, ,,in many cases, the Church acknowledged the emperors' rights to appoint bishops in certain areas by themselves, without any objection. This right of the rulers was not in contrary to the order of the $30^{\text {th }}$ Apostolic Canon (or $3^{\text {rd }}$ Canon of the Seventh Ecumenical Council), since this Canon was not intended against the rulers (pointed out by the author), but against a forcible influence over the episcopal selection coming from the civil servants". ${ }^{20}$

The ruler could exercise this power in two ways: either to confirm the Council's selection or to nominate his own candidate. In the latter one, the Council would subject the nominated candidate to a canonic exam in order to determine his worthiness. In case of a negative result, the ruler would appoint another candidate. ${ }^{21}$

So, in both cases there was a cooperation between the secular and church powers with mutual respect, which was not the case in $\mathrm{BH}$ because the Austro-Hungarian

${ }^{19}$ The Christian Church commenced its cooperation with the state authorities and officially entered the public sphere on the basis of the Edict of Milan in 313. Since that time, rather complex relations between the state and the Church had begun. After three centuries of prosecution by the Empire, the Church found itself in a new situation that carried new temptations with it, both in terms of the inner-church affairs (great heresies and the schism) and the relations with the State. The state relations were far from ideal. The first Christian confessor that clearly set the boundaries between the religious and the secular powers, and their jurisdictions, was Patriarch Athanasius of Alexandria by mid-4th century in his work „The history of Arians”. Beside St Athanasius, the relations between the state and Church powers were written about St Ambrose of Milan in 4th century. For more information on this topic, see the works of S. Šarkić: „Shvatanja Atanasija iz Aleksandrije o monarhiji“, Collection of papers from the Faculty of Law in Novi Sad, no. 3/2008, 55-67, „Pravne i političke ideje Ambrozija od Milana” Collection of papers from the Faculty of Law in Novi Sad, no. 1/2009, 21-37.

${ }^{20}$ Milaš, N. Pravoslavno crkveno pravo, Belgrade-Šibenik 2004, 382. Milaš's attitude is based on several state and church legal acts, such as: Decree of Tsar Nikephoros II Phocas (10th century), a decree by Tsar Issac Angelos (12th century), and a decision from the Patriarchate of Constantinople dating from 1317. For more details, see Milaš (2004), 383.

${ }^{21}$ Ibid. 
Emperor had no interest in providing his cooperation during the episcopal appointment procedure (although he was later forced to cooperate due to diplomatic reasons). By the means of the ill-gotten legal act, i.e., the Convention, he was bluntly breaching all canonic regulations on the episcopal selection process, which is an example of despotism and violence of the state law over the canonic law.

This attitude created new problems for the Church in BH including: the issue of the state powers participation in the hierarchy selection procedure, and the issue of the canonic status of bishops, i.e., the metropolitans that were being selected in this way. In other words, it should be analysed in more details under which circumstances and in what way the Church can accept the involvement of secular powers in the selection and dismissal procedure of its hierarchy.

Bishop Atanasije (Jevtić) gives partial answer to the first question referring to the Justinian's Novella 123,1. Bishop Atanasije states that in $6^{\text {th }}$ century it was a common practice for lower clergy to take part in the bishop selection procedure along with the city leaders, i.e., state officials. However, their role was to choose three candidates fit for the title, in their opinion, and to communicate that proposal to the Council that would later on chose one of them. ${ }^{22}$ So, no solution was to be imposed by the authorities, and such procedure was acceptable to the Church (it should be pointed out that in this case it was about the representatives of the state that were church people at the same time).

For instance, until the fall under the Ottoman Empire, the primate of the Serbian Orthodox Church had been chosen by the state council presided by the ruler, and consisted of high hierarchy and high nobility. ${ }^{23}$

It should be emphasized that there was a difference between the procedures for the selection of a patriarch, i.e., the primate of a church, and a bishop. The difference was due to uniqueness of the patriarch's service and position.

When talking about this subject, we have to mention that it was common in the medieval Orthodox Christian states to have a patriarch chosen by the ruler.

N. Milaš says that ,the canonic regulations on the selection of metropolitans, as independent primates of their churches, were applied, initially, to the patriarchs as well. Namely, they were chosen by a competent district or county council, the very one introducing them to the service. Later on, the right to appoint the patriarch to the office was passed on to the state authorities, i.e., the ruler as a church protector." 24

So, the participation of rulers in the hierarchy selection procedure was not alien to the Church but that right was predominantly exercised by the ruler for the church primate selection process.

\footnotetext{
${ }^{22} \operatorname{SCC}$ (2005), 208.

${ }^{23}$ Ljubomirka Krkljuš, Pravna istorija srpskog naroda, East Sarajevo 2007, 55.

${ }^{24}$ Milaš, N. (2004), 360-361.
} 
St Symeon of Thessalonica ( $15^{\text {th }}$ century) says the following about the nature and the method of ruler's involvement in the patriarch selection procedure: „It is not the Tsar only that appoints patriarch but the council; and being an orthodox, the Tsar only takes part in it, not just because he is the Church protector and the Lord's anointed but to protect and give greater power to what the Church is doing through his presence and participation." 25

The right of a medieval ruler to choose a patriarch came from this function of the Church protector. That right was justified by the fact that the ruler used his power to fortify the legitimacy of the chosen patriarch, i.e., to make the Church decisions final.

Also, new dioceses were founded during state councils, but the episcopal selection procedures for these dioceses were taking place during the church council. Appointment to these new dioceses by the Church was considered as its internal affair.

However, there were cases when bishops were chosen and appointed by the Tsar. On this account, Milaš concludes that some bishops were appointed even without the formal selection. In other words, no appointment procedure took place, but instead they were directly appointed by the state authorities. Also, ,after such appointments, they would be subjected to the canonical exam by the relevant bishops and the metropolitan, and upon the consecration for being found worthy, issued a confirmatory charter. This practice had been initiated by the Church at the time of the Greek-Roman emperors that proclaimed themselves as the Church protectors, approving its great privileges before the law. The Roman state law according to which a part of the public law (ius publicum) was consisted of ius sacrum was in favour of such practices." 26 According to Milaš, these bishop appointments by the rulers often depended on the circumstances.

In this case as well, the ruler's right to appoint bishops was considered to come from his role of the church protector, as well as on the basis of an interpretation of the Roman law on the relations between the church and the public law. The ruler exercised this right less frequently than the right to appoint the patriarch, and predominantly in extraordinary situations.

As for the case being analysed, when it comes to the interference of the authorities in the Church matters, they were not its representatives or members of the Serbian Orthodox Church, and neither had the intention to protect it, but instead it was a case of a brutal imposition of the solutions, completely unknown to the canonic Church tradition. The role of the Church for the selection of metropolitans was reduced to a pure formality, only keeping the canonic way for the imposition of the new bishops (Article 4 from the aforesaid Convention). In this case, the

\footnotetext{
${ }^{25}$ Ibid.

${ }^{26}$ Milaš, N. (2004), 382.
} 
selection was completely non-canonic, and the chirotony itself (consecration) was canonic and regular.

If questioning the canonic evaluation of this type of election, the answer might be sought after in the following facts: even before the occupation, Phanariot bishops had been imposed to the Serbian Orthodox metropolitanates in BH by Constantinople. Although the people and the lower clergy had no role in the selection procedure, these bishops had been ordinated canonically (the problem was not in the form of the ordination, but in the selection procedure, and their subsequent behaviour towards the flock and the lower clergy). The selection method for these bishops was mainly irregular and unacceptable from the canonic point of view, because it was based on simony, i.e., bribe. The punishment for this breach was a displacement and a complete excommunication, both the bribed and the briber. ${ }^{27}$ Still, the accusations of simony needed to be proven in a regular churchcourt procedure in order to remove the accused from the office. Such church-court procedure was not possible in $\mathrm{BH}$ during the period at stake, and those bishops would stay in power. In this case, the Church had to adjust to the circumstances, but still, in spite of major canonic irregularities, managed to preserve its essence and its main goal: materialization of itself as the Body of Jesus through history.

L. G. Patsavos explains the possibilities for the Church to keep its essence and identity, regardless of the serious disturbances of its canonic order stating: „...it should not be forgotten that we must not equate the Church with its rules. The most important is not to mix the Gospel with Pidalion (codex of canons - added by the author), theology with legislation, and ethics with the science of law. The canons are at the service of the Church, with the purpose to direct the Church members on the way to the salvation, as well as to make that journey easier. Church legislation is only one of the aspects of the Church life, and above all, it does not represent its essence. Church is a mystical Body of Christ, however, its presence through history has inevitably led to the formation of the legal system and legal institutions."28

On the basis of Patsavos's explanation, an argument can be made, when it comes to the complex relation between the Church and its canonic principles, that the Church is not a slave to its canons, but has brought the canons forth and lived according to them. In other words, the rules have not been imposed to the Church from the outside. It would be wrong to conclude that the canons have nothing to do with the essence of the Church because they are an expression of its essence through history. More correct conclusion would be that the Church has the power to endure unfavourable historic circumstances under which its canonic tradition is affected by keeping its identity and fulfilling its main purpose: to iconise the Heavenly Kingdom in time and space.

\footnotetext{
${ }^{27} \mathrm{SCC}(2005), 44$.

${ }^{28}$ Lewis J. Patsavos, Duhovne dimenzije sveštenih kanona, Kragujevac 2009, 16.
} 
There are even cases in the Church history when schismatics, following their regression to the Church, were recognized their pastoral and bishop ranks gained during the period of schism even without the reordination with a written confession of the Church dogmas, anointment and repentance. That was the case with the Cathars whose return to the Church was regulated by the $8^{\text {th }}$ canon of the First Ecumenical Council. ${ }^{29}$

So, in these cases the Church applied the economy (condescension) to some individuals or groups of people with an aim to preserve its own unity and to bring back the apostates under its tutorship.

Only through the prism of the church economy, it is possible to give a positive church-law point of view on the situation our Serbian church in BH found itself in. Also, the Church had managed to preserve its identity during the selection procedures of the Phanariot bishops, which were canonically irregular, in the Ottoman period. These bishops were acknowledged and recognized by the Church as true, canonic ministers in case they had deserved such position through their deeds and the relation with the Church and the flock. The Church in BH has remained as one, holly, catholicon, and apostolic church, in unity with all other orthodox Churches in terms of liturgy, which is the main criteria for the truthfulness and fullness from the aspect of Orthodox ecclesiology. Here it is interesting to point out the opinion of $\mathrm{D}$. Ruvarac who says that metropolitan selection procedure, in those days, was not canonic, but was also not in contrary to the church practices of that time in all of the constitutional and absolutistic countries. ${ }^{30} \mathrm{At}$ the end, the Church showed its powers and potential to overcome problems like these without betraying its essence and the mission.

\section{SELECTION OF METROPOLITANT SAVA KOSANOVIĆ}

As for the metropolitan selection and dismissal procedure for the Serbian Orthodox metropolitanates in $\mathrm{BH}$ during the time period analysed herein, it should be pointed out that the actual circumstances were different to some extent from the theory. On the basis of the Convention between the Austria-Hungary and the Patriarchate of Constantinople, the Austrian Emperor was given unambiguous rights, as the time would show, to choose and dismiss metropolitans (Article 2). However, according to the first item, the current metropolitans could be removed from the office only with the assent of the Patriarchate of Constantinople, i.e., the Emperor was to inform the Patriarch, before the appointment of the new metropolitan, on the person at stake, so that the Patriarch could carry out the „canonic

${ }^{29}$ See the explanation of Bishop Athanasius SKC (2005), 72-73.

${ }^{30}$ D. Ruvarac, Ustav crkvene i školske samouprave srpsko-pravoslavnog naroda u $\mathrm{BiH}$ sastavljen dr Emilom Gavrilom, prikazan protojerejem Dimitrijem Ruvarcem, Zemun 1899, 39-41. 
formalities." In theory, the Patriarchate was not completely excluded from the metropolitan selection and dismissal procedure in BH. Vienna wanted to have a complete power in BH, and, on the other hand, didn't want to confront the Patriarchate of Constantinople for diplomatic and political reasons.

The Convention was first applied practically during the selection procedure of a new Sarajevo metropolitan following the resignation of Metropolitan Anthim in 1881. The circumstances were quite new to all of the participants - Constantinople, Vienna, and for Archimandrite Sava Kosanović himself, who had already been proposed for the metropolitan rank back in the Ottoman days.

The National Government in Sarajevo was in a constant contact with Vienna and the Mission in Constantinople. It was now necessary to demonstrate, in action, that the Convention was indeed a lawful binding act whose provisions had to be obeyed. On the other hand, the Austro-Hungarian representatives in Sarajevo, particularly in Vienna, were aware of the fact that their attitude was not to be too rigorous in order to maintain the good relations with the Patriarchate of Constantinople.

In 1879, the Church-School Municipality in Sarajevo sent a request to the Patriarch asking for an ordination of Sava Kosanović to metropolitan office in Sarajevo. The Patriarch agreed and sent a letter asking of Sava Kosanović to come to Constantinople for the ordination in order to be appointed as Metropolitan Athim's deputy. As soon as the government in Sarajevo came to know about this event, it immediately informed Vienna. Then, the Austrian representatives in Constantinople managed to arrange for a temporary delay of the new metropolitan nomination by the Patriarch while Kosanović was prohibited from going to Constantinople. When realised Kosanović had no competition for the metropolitan post, it was decided to appoint him to the throne of Sarajevo Metropolitanate anyway.

It should be pointed out that the Patriarchate did also have an important role in the selection and appointment procedure because it was only after its confirmation of Kosanović's appointment that the proposal was sent to the Tsar, who later on approved it. ${ }^{31}$ In this case, it is true that the consultations with the Patriarchate were extorted on political and diplomatic grounds. Also, because of the way Sava Kosanović was elected in, it was obvious that the Convention would be a temporary, and not quite unconditional and strict legal act.

It should be stressed that this claim was confirmed by Sava Kosanović's acts. Namely, before his own selection procedure and not to the knowledge of the National Assembly, he had asked the people, i.e., the Sarajevo church-school municipality, for their assent. The Patriarch himself, was against the participation of the people in the metropolitan selection procedure, but in the end, he gave up because Kosanović firmly claimed he would not accept the metropolitan rank without the

${ }^{31}$ Madžar, B. (1982) 63-64. 


\section{people's will. The Patriarch was forced to address the Church-School Munic- ipality of Sarajevo with an official dispatch asking for its approval. ${ }^{32}$}

Not only was this act in breach of the Convention provision, which had no mention of people during the metropolitan selection, but an exception was made by giving the right to the church-school municipality, i.e., the laymen, to have an important role in the high church hierarchy selection procedure. ${ }^{33}$

During the chirotony of Sava Kosanović, the Emperor confirmed his sovereignty over $\mathrm{BH}$ by his diploma on appointment read before the public. ${ }^{34}$ The state used official occasion to demonstrate its powers and the final goal - the annexation of BH. However, the newly appointed metropolitan did not waste the opportunity to confirm, once again, the way he had been selected in before the public. Namely, during his first addressing to the believers, he announced, in the form of an epistle, that he had been chosen by the will of the Synod (remark made by the author) and the Emperor. ${ }^{35}$ In the spirit of the Orthodox canonic tradition, the metropolitan was clear about who he considered to be his primary superior. After his resignation, the issue of people's participation in the high hierarchy selection was brought up for the first time or, in other words, the Emperor's right to choose and appoint metropolitans was opposed. As it turned out, this question was crucial and was a stumbling stone during the subsequent negotiations between the representatives of the church-school authorities in $\mathrm{BH}$.

Apart from this case, the examples of the two Sava Kosanović's successors to the throne of Sarajevo Metropolitanate should be mentioned as well. Sava Kosanović was succeeded by Metropolitan Georije Nikolajević. The following is concerning his selection:" the resignation of Metropolitan Sava was accepted on $10^{\text {th }}$ of September 1885, and the Viennese Court appointed Archimandrite Nikolajević as an administrator of the Metropolitanate of Dabar-Bosna. In the same year, he was chosen for the metropolitan of Dabar-Bosna by the Patriarchate of

32 Ibid.

${ }^{33}$ During the rule of the Ottoman Empire, the people had the right to choose its priests and teachers, as well as to take part in the selection procedure of the Patriarchate of Constantinople through their representative. It is unclear whether the people had the right to take part in the bishop selection procedure. In its complaint to the Patriarchate over the secret signing of the Convention in 1880 , the church-school municipality of Sarajevo stated that the Serbian people was in the position to choose their own metropolitans, later on ordinated by the Patriarch, during the Ottoman rule - see B. Madžar (1982), 36. However, in the so called First Emperor Memorandum, from the year of 1896, by which 14 representatives of the Serbian church-school municipalities in BH addressed to the Emperor in Vienna, nowhere in the text did they mention the people's rights to choose their own metropolitans during the Ottoman reign. Such right might have existed, but it is clear that it was not exercised because of the way the Phanariotes came to the throne of the Serbian Orthodox eparchies in $\mathrm{BH}$.

${ }^{34}$ Madžar, B. (1982) 66.

${ }^{35}$ Ibid. 
Constantinople among other three candidates. The other two were Metropolitan Varne Kalinik and Bishop Lernički Danil." 36

The same is cited for the selection of Nikolaj Mandic for the position of Zvornik-Tuzla bishop, the subsequent metropolitan of Dabar-Bosna. ${ }^{37}$

It is visible that the Synod was choosing a metropolitan among other three candidates with an agreement and consent of the state authorities. This metropolitan selection method was completely opposed to the Convention provisions clearly stating that the Patriarch's only right was to know the name of the future metropolitan before the appointment to be able to fulfil canonic formalities. ${ }^{38}$

In practice, the Convention was often breached to the detriment of the state powers, which were often appeasing the Patriarchate of Constantinople. An obvious suspension and relativization of an official legal act is at stake here, showing not so much an impotence of the state in relation to the Church, but rather calculations of the representatives of the state politics and diplomacy.

\section{DISSMISAL OF METROPOLITANS}

As for the authority dismissing a bishop, the Church canonic tradition implies the same as for the selection procedure. The one with the right to choose also has the right to dismiss bishops. So, this right belongs to the episcopal Council exclusively, with a prior trial of the accused (the Second Ecumenical Council, 6; the Fourth Ecumenical Council, 9, etc.). The first two represent the main indicator of the autocephaly of a local church.

The following took part in the procedure for the selection of new metropolitans in BH during the period analysed: the Austrian Emperor and the Patriarchate of Constantinople. According to the Convention provisions, the state could choose and appoint new metropolitans without the participation of the Patriarchate or with its participation, which was reduced to a mere formality. Still, the National Government had first asked for the Patriarchate consent at the time of the Sava Kosanović selection, and only after receiving the positive reply the proposal was sent to the Emperor. As already mentioned, the Patriarchate played even a bigger role during the selection procedure of Georgije Nikolajević and Nikolaj Mandić.

When it comes to a high hierarchy dismissal, the situation was as follows: since a bishop dismissal process was a very difficult and an undesirable act for the Church even under the normal circumstances, and therefore prolonged for as long as possible, such a complicated and burdensome event would get negative proportions during the period analysed. The only metropolitan dismissed upon the

\footnotetext{
${ }^{36} \mathrm{http}: / /$ www.mitropolijadabrobosanska.org, August 20th 2018

37 Ibid.

${ }^{38}$ Madžar, B. (1982), 33-34.
} 
will and initiative of the state authorities at the time was Metropolitan of Tuzla-Zvornik Dionysius II in 1891. According to the 1880 Convention, the Emperor had the full power to dismiss metropolitans but with the patriarchate consent (Article 1 from the Convention). Due to the sensitivity of this issue, the Patriarch, i.e., the Synod was granted the rights to participate in the metropolitan dismissal procedure by the very Convention.

Once the whole situation is taken into consideration, it is clear why no Serb metropolitan was ever dismissed in practice. It was clear to the authorities that such move would cause turbulent reactions in the Serbian Orthodox people, and even lead to conflicts on a large scale. The National Government did not give up on its goals but instead acted in accordance to its plan for each situation separately choosing its methods with more care and caution. The same rule would be applied in case of a possible metropolitan dismissal.

As for Metropolitan Dyonisis II, he had already had a conflict with the Patriarch, and the Patriarch himself asked Vienna for his dismissal. The government officials gathered substantial evidences on malpractices and violations of the canonic regulations by Metropolitan Dyonisis II. On the basis of this exhaustive and documented accusation, the Emperor dismissed him in 1891 with the Patriarch's consent. ${ }^{39}$

The Emperor and the Patriarch acted together in this case as well, indeed upon the initiative of the first one that resulted from a long-lasting consideration of the situation by the Vienna representatives in Sarajevo.

\section{RESIGNATION OF METROPOLITAN SAVA KOSANOVIĆ IN 1885}

Apart from the canonic evaluation of the cases of selection and dismissal of metropolitans of the Serbian Orthodox metropolitanates in BH during the Austro-Hungarian rule, the same retrospect should be made of another instance in the Church life during this period. It is about the case of metropolitan resignation. Resignations were more often in practice than dismissals due to political and diplomatic reasons already mentioned. The following Phanariotes resigned from their metropolitan services and positions: Metropolitan of Dabar-Bosna Anthim in 1881, Bishop of Zahumlje-Hercegovina Ignatius in 1888, and Metropolitan of Dabar-Bosna Sava Kosanović in 1885.

As far back as 1879 , Metropolitan Anthim requested his own retirement, and his main demand was a solid and assured pension incomes. ${ }^{40}$

\footnotetext{
${ }^{39}$ Madžar, B. 1982), 54-59.

${ }^{40}$ Ibid., 48.
} 
Metropolitan Ignatius, who had a sneaky nature and was capable of all sorts of intrigues in order to gain some benefits, was causing more problems to the authorities.

Metropolitan Ignatius was having conflicts and reconciliations with everyone, both the Church-School Municipality in Mostar, the Patriarchate and the National Government. The right moment for his dismissal was being waited for. It came in 1887 when the Patriarchate of Constantinople decided to take away Pljevlja and Prijepolje from the Metropolitanate of Zahumlje-Hercegovina, and conjoin them to the Metropolitanate of Prizren..$^{41}$ The metropolitan raised his voice against this decision and decided to resign, which was exactly what the government officials presided by Benjamin Kalaj, the mutual minister of finances, were waiting for. They supported the Patriarch, and provided the metropolitan with the pension on condition of his loyalty to Vienna. ${ }^{42}$

These cases show the ways the new authorities were acting in for the sake of their own interests.

In accordance with the aim of this paper, it is necessary to take a look at these cases from the canonic point of view. Although rare and not a rule but an exception, the Orthodox canonic tradition is familiar with the possibility of episcopal resignation. The Church would consider these cases individually being governed by economy, i.e., condescendence towards the bishops applying for a resignation, allowing them to keep the episcopal rank and perform all divine services with the blessings from a competent bishop. According to Bishop Atanasije Jevtić ,the canon (the $16^{\text {th }}$ First and Second Council of Constantinople) clearly states that there can be a voluntary resignation of a bishop from episcopal service/diocese, and that he is not be put on a trial nor sentenced. ${ }^{443}$ There Church has cases of resignation recorded through its history, as such the case of St Gregory the Theologian, St Sava of Serbians, and Constantinople patriarchs Ignatius and Photios. In spite of their resignations, they have been recognized and accepted as the holies by the Orthodox Church.

There are two canons that regulate the issue of episcopal resignation: canon 3 from the Third Ecumenical Council (431), and canon 16 from the First and Second Council of Constantinople (861). According to the latter one, a new bishop is not to be appointed to a cathedra until the current bishop submits his written resignation, and both of the canons are about the cases of episcopal resignations due to external pressures. Therefore, the canons were applied to the case of Metropolitan Sava Kosanović's resignation. Photios of Constantinople was in as almost identical situation as Metropolitan Sava in terms of the relations with the state

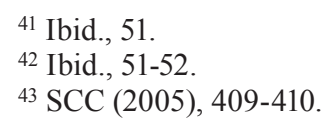


powers when filing for the two of his resignations. ${ }^{44}$ On the basis of this similarity, it can be concluded that there were no canonic irregularities concerning the Sava Kosanović's resignation, just as the case was with the resignation of Patriarch Photios. The reason this fact is being mentioned here is because there are those within the Church that believe a bishop is not to file a resignation under any circumstances. ${ }^{45}$

However, as previously mentioned, resignation is not strange to the canonic Church tradition, but it should be viewed as an exception rather than a rule.

The case of Metropolitan Sava was a confirmation of such Church attitude. His resignation was refused by the Patriarchate of Constantinople at first reasoning that he as ,,a true Church soldier should endure regardless of all hardships". ${ }^{46}$ Still, later on, because of the metropolitan's insisting and the pressures coming from Vienna, the Patriarchate accepted his resignation. So, in this case also, Metropolitan Sava didn't breach the Church canonic law although his act was rather unusual from the church-law aspect.

\section{CONCLUSION}

The incorporation process of the Serbian Orthodox metropolitanates in Bosnia and Herzegovina into the state-legal order of the Austro-Hungarian Empire was initiated immediately after the occupation. It lasted until 1905 when the Statute for the church-educational administration of the Serbian Orthodox eparchies in BH was adopted, on the basis of which the legal status of the Serbian Orthodox religious community in Bosnia and Herzegovina was finally regulated. The results of this process were not ideal nor perfect for the Church. The head of the state was often referring to the canonic law, but was breaching it even more often by a selective application depending on its interests. Still, the Church in spite of such extremely difficult conditions managed to preserve its essence and identity regardless of the canonic deviations resulting from the influence of the nonSlavic state powers, as shown concretely on the examples of high hierarchy selection and dismissal procedure.

${ }^{44}$ Ibid.

${ }^{45}$ Such attitude is expressed in the third canon of St Cyril of Alexandria. This great Father and Church teacher says that it is not fit for a bishop to resign, and that he can resign from his cathedra only if deposed by the Church because of the proven offences, SCC (2005), 535.

${ }^{46}$ Madžar, B. (1982), 82. 


\section{REFERENCES}

Rajko Veselinović, „Srpska pravoslavna crkva u Bosni i Hecegovini“, Srpska pravoslavna crkva od 1219-1969. Spomenica o 750-godišnjici autokefalnosti, Beograd 1969, 319-329.

Sava Vuković, Srpski jerarsi od devetog do dvadesetog veka, Novi Sad 2012.

Radoslav Grujić, Pravoslavna srpska crkva, Beograd - Kragujevac 1995.

Svetislav Davidović, Srpska pravoslavna crkva u BiH (960-1930), Novi Sad 1998.

Jovan Dajković, „Ostavka mitropolita hadži Save Kosanovića“, Glasnik SPC 40, Beograd 1959, 112-118.

Nićifor Dučić, Istorija Srpske pravoslavne crkve (od prvijeh desetina VII v. do naših dana, Gacko, 2002.

Milorad Ekmečić: „Društvo, privreda i socijalni nemiri u BiH“, Istorija srpskog naroda VI-1, Beograd, 1994, 555-603.

Milorad Ekmečić:"Nacionalni pokret u BiH“", Istorija srpskog naroda VI-1, Beograd, 1994, 604-648.

Istočnik, duhovni list za crkveno-prosvjetne potrebe srpsko-pravoslavnog sveštenstva u BiH, godina XIX, br. 8. i 9. 1905.

Tomislav Kraljačić, Kalajev režim u Bosni i Hecegovini (1882-1903), Sarajevo, 1987.

Ljubomirka. Krkljuš, Pravna istorija srpskog naroda, Istočno Sarajevo, 2007.

Božo Madžar, Pokret Srba Bosne i Hercegovine za vjersko-prosvetnu samoupravu, Sarajevo, 1982.

Đorđe Mikić, „Austro-Ugarska okupacija i pravoslavna crkva“ Eparhija Banjalučka 1900-2000 (šematizam), Banjaluka 2000.

Nikodim Milaš, K pitanju o jerarhičkom položaju sarajevske mitropolije, Novi Sad, 1886.

Nikodim Milaš, Pravoslavno crkveno pravo, Beograd-Šibenik, 2004.

Luis Dž. Patsavos, Duhovne dimenzije sveštenih kanona, Kragujevac, 2009.

Predrag Puzović, „Srpska crkva u Bosni i Hecegovini”, Srpska pravoslavna crkva - prilozi za istoriju 2, Beograd, 2000, 23-29.

Predrag Puzović, Sarajevska bogoslovija 1882- 2002, Srbinje, 2003.

Predrag Puzović, Srpska pravoslavna Eparhija Dabrobosanska (šematizam), Srbinje, 2004.

Predrag Puzović, „Srpska pravoslavna crkva u Bosni i Hercegovini od Berlinskog kongresa do aneksije 1908.godine“, Zbornik radova sa naučnog skupa „Stogodišnjica aneksije BiH”, Banjaluka 2009, 65-87.

Dimitrije Ruvarac, Ustav crkvene i školske samouprave srpsko-pravoslavnog naroda u BiH sastavljen Dr. Emilom Gavrilom, prikazan protojerejem Dimitrijem Ruvarcem, Zemun, 1899.

Skarić, V., Nuri-Hadžić O., Stojanović, N.: „Versko-prosvetna borba pravoslavnih Srba“, Bosna i Hercegovina pod austrougarskom upravom, Beograd, 1938, 33-55.

Svešteni kanoni Crkve, prevod sa grčkog i slovenskog Episkopa Atanasija umirovljenog Hercegovačkog, Beograd, 2005. 
Đoko Slijepčević, Istorija Srpske pravoslavne crkve,Knjiga 2, Od početka XIX veka do kraja Drugog svetskog rata,Zemun 2002.

Srđan Šarkić, „Shvatanja Atanasija iz Aleksandrije o monarhiji“, Zbornik radova Pravnog fakulteta u Novom Sadu, 3/2008, 55-67.

Srđan Šarkić, „Pravne i političke ideje Ambrozija iz Milana“ Zbornik Pravnog fakulteta u Novom Sadu, 1/2009, 21-37.

www.mitropolijadabrobosanska.org

www. srbiubih.com.

www.uzzpro.gov.rs. 
Marko D. Tomić, student doktorskih studija

Univerzitet u Beogradu

Pravni fakultet u Beogradu

tomicmarko@hotmail.com

\section{Ogled o pravnom položaju Srpske pravoslavne crkve u Bosni i Hercegovini pod Austrougarskom vlašću ${ }^{47}$}

Sažetak: U radu se razmatraju određeni aspekti početne faze procesa inkorporiranja srpskih pravoslavnih mitropolija u Bosni i Hercegovini u državnopravni poredak Austro-Ugarske sa crkvenopravnog tj. kanonskog aspekta. Pravni položaj srpskih mitropolija u BiH u vremenu neposredno posle Berlinskog kongresa rešavan je na relaciji Beč-Carigrad. Konačni ishod pregovora između Carigradske patrijaršije i Bečkog dvora bila je Konvencija o privremenom rešenju odnosa srpskih pravoslavnih mitropolija u BiH sa Carigradskom patrijaršijom iz 1880. godine. Glavni deo rada bavi se analizom odredbi Konvencije o izboru $i$ smeni više jerarhije sa crkvenopravnog aspekta. Potom se na osnovu konkretnih primera iz života Crkve daje procena ovih događaja sa stanovišta kanonskog prava.

Ključne reči: Srpska pravoslavna crkva u Bosni i Hercegovini, Austro-Ugarska, Carigradska patrijaršija, jerarhija, crkveno (kanonsko) pravo.

Datum prijema rada: 30.10 .2018 .

${ }^{47}$ Radi preciznosti treba napomenuti da Srpska pravoslavna crkva u BiH u austrougarskom periodu zvanično nije nosila naziv koji je dat u naslovu rada, ali pošto se radi o izrazu koji je u široj upotrebi u domaćoj istoriografiji, on je u samom naslovu i naveden. Zvanični naziv je bio Srpske pravoslavne mitropolije u $\mathrm{BiH}$ (pod jurisdikcijom Carigradske patrijaršije). U samom radu, paralelno se upotrebljavaju oba izraza. 